\title{
Improving The Ability Of Teachers To Arrange Knowledge Aspect Assessment Instruments Through Collaborative Academic Supervision
}

\author{
Sumadi; Bambang Ismanto \\ Masters Study Program of Education Management \\ Faculty of Teacher Training and Education \\ Satya Wacana Christian University \\ sumadi140765@gmail.com
}

Article received: March 2021; revised: April 2021 ; accepted: April 2021

DOI : 10.17977/um025v5i22021p101

\begin{abstract}
This study aims to improve the ability of teachers to compile instruments for assessing aspects of knowledge through collaborative supervision in Kenteng 01 Elementary School, Bandungan District. This type of research is a school action research with a qualitative descriptive approach. The research subjects consisted of school principals and 6 teachers at Kenteng 01 Elementary School. Data collection techniques were done through observation, interviews, and documentation studies. Data analysis techniques used are data collection, data analysis, data reduction, data presentation, and conclusions. This research was conducted in two cycles through planning, implementation, observation, and reflection. The results showed that after academic supervision in cycle 1, the average score was $78.9 \mathrm{C}$ (enough). In cycle 2 the average score was 90.4 in the good category (B).
\end{abstract}

Keywords: Academic Supervision, Collaborative, Teacher Ability, Assessment Instrument

Teachers have a key role in realizing educational goals. The purpose of education will be successful if the teacher becomes a professional educator. Therefore, teaching must be accountable (Kusumaningrum, et.all, 2019). It is emphasized that the task of teachers other than teaching and educating has the task of carrying out assessment (Law Number 14 of 2005; Permendikbud Number 15 of 2018). The law mandates that the task of assessment is the main task which is the responsibility of a teacher. This task can be carried out well if the teacher has sufficient competence. Teacher professional development (PD) is essential for improving student outcomes. Because PD involves a multidimensional structure and changes throughout the professional life of the teacher (Sancara, et.all., 2021). In the aspect of pedagogical competence, teachers have to understand the aspects of assessment, planning instruments, carry out assessments in accordance with assessment procedures and principles and compile reports on assessment results (Permendiknas No. 16 of 2007 concerning Teacher Competency Standards)

The assessment aspects of the 2013 curriculum include the assessment of attitudes, knowledge, and skills (Permendikbud Number 23 of 2016). Attitude assessment is carried out by observing the behavior of students. Assessment of knowledge is carried out through tests aimed at reasoning and critical thinking skills. For the assessment to be successful it needs to be well planned. Teachers need to understand and master the aspects in the preparation of assessment instruments. Good mastery of the aspects of the assessment will provide clear directions and targets so that it is easy to determine forms, techniques, instruments according to basic competencies, indicators of competency achievement. As a reference for assessment standards, the three aspects of the assessment must be carried out comprehensively. To carry out standardized assessments, it needs quality instruments. The quality of the assessment instrument will determine the success of the assessment itself. The assessment instrument was made as a tool for obtaining data on student learning outcomes and for measuring the achievement of learning objectives and functions as a report document. The assessment instrument designed by the teacher and the learning outcome report document is evidence that the teacher has carried out an authentic assessment. 
One of the indicators of authentic assessment carried out by the teacher is the availability of planning documents, implementation, and assessment results. Based on observations, generally, all the teachers of SDN Kenteng 01 have carried out the assessment. However, the instrument planning category is still less. The results of preliminary observations at SDN Kenteng 01, Bandungan District shows that the assessment instrument on the average aspect of knowledge is still in the poor category. The results of pre-cycle observations show that 1 teacher is in the sufficient category and 5 teachers are in the poor category. The results of the preparation of questions do not necessarily fulfill the rules of good questions. The results of the interviews showed that they still had difficulties in compiling the knowledge assessment instrument, so they copied and pasted the existing questions and found many questions that were not in accordance with the basic competencies being taught. If there are no further efforts, it will have an impact on the quality of education at SD Negeri Kenteng 01 . Then it is necessary to make efforts to improve the ability of teachers, through academic supervision. Supervision is a competency inherent in the principal duties of school principals including planning, implementing, evaluating, and following up on the results of supervision (Permendiknas No.13 of 2007). Supervision is carried out by the school principal of SDN Kenteng 01, but the supervision is carried out to the maximum. Based on observations and interviews with the school principal and teachers at the beginning of the study, it is known that supervision, which was in the form of general coaching, has not focused on assessment issues. The school principal needs to understand supervision so that the supervision is carried out according to the expected goals. Supervision is an effort to provide services to teachers to improve learning (Sahertian, 2010: 19). From this idea, supervision is an effort to help teachers improve professionalism, so that the quality of learning is going better and has an impact on the quality of students.

Academic supervision carried out in this study is focused on improving the ability of teachers to develop knowledge assessment instruments. The academic supervision approach used in this study is a collaborative approach, namely an approach that combines direct and indirect approaches. The collaborative approach was chosen because this approach it is carried out with two-way communication which allows supervisors and teachers to jointly discuss democratically solving problems faced by the teacher. Furthermore, Ulfatin, et.all (2020) this sharing shows that the principal always encourages the involvement of teachers in professional development programs and uses their skills for the benefit of school development. In addition, it is clear from the analysis that the principal studied has skills in resolving internal crises, exhibits flexible and responsive administrative characteristics, and supports teacher recommendations for school improvement.

Based on the problem of the weak ability of teachers in compiling assessment instruments in SDN Kenteng 01, Bandungan District, Semarang Regency and paying attention to the results of previous studies, a school action research was carried out with the title "Improving Teachers' Ability to Prepare Assessment Instruments for Knowledge Aspects through Collaborative Academic Supervision at Kenteng 01 Primary School. Bandungan District".

Academic supervision contributes to increasing teacher competence. This study aimed at improving the ability of teachers to develop knowledge assessment instruments through collaborative academic supervision and to find out the steps for collaborative academic supervision to improve the ability of teachers to develop knowledge assessment instruments at SDN Kenteng 01, Bandungan District.

\section{METHODS}

The type of research used in this study is School Action Research. The research approach is a qualitative descriptive approach. The qualitative research method is a naturalistic research method because the research is in natural conditions (Sugiono, 2014). This action research was conducted in 2 cycles. Each cycle went through 4 steps, namely planning the implementation of observation and reflection. The research subjects were the school principal and 6 classroom teachers at SDN Kenteng 01, Bandungan District. Data collection techniques through observation, interviews and documentation study. Data collection techniques used interview guidelines and document study and question analysis instruments. The data analysis technique for the teacher's ability to compile an instrument for assessing 
aspects of knowledge from pre-cycle to the end of cycle 2. Quantitative data analysis is described qualitatively in predicates defined, namely: $\leq 70=\operatorname{Less}(\mathrm{D}) ; 71-80=$ Fair (C); 81-90 = Good (B); 91-100 $=$ Very Good (A). To determine the improvement and the level of success of the action by comparing the average score from pre-cycle to cycle 2 it is converted to the predicate value and the indicator of research success. The validity of the data in this study used the triangulation method of sources and techniques. Technique triangulation is conducted by checking data from the same source with different techniques. Meanwhile, the researcher did the triangulation of sources by checking the data obtained through the number of subjects. The indicator of the success of this research is that after academic supervision with a collaborative approach is carried out there is an improvement in the ability of teachers to develop knowledge assessment instruments and at least $83 \%$ of teachers achieve B predicate (Good).

\section{RESULTS AND DISCUSSION}

This research begins with a pre-cycle. From the observation, it is known that the average teacher's ability to arrange knowledge assessment instruments is still in the poor category as shown in Table 1.

\begin{tabular}{lccc}
\multicolumn{4}{c}{ Table 1. Average Score of Teacher Ability to Arrange Pre-Cycl } \\
\hline No & Name & Average & Predicate \\
\hline 1 & Teacher 1 & 69.9 & D (Less) \\
2 & Teacher 2 & 69.7 & D (Less) \\
3 & Teacher 3 & 69.6 & D (Less) \\
4 & Teacher 4 & 66.4 & D (Less) \\
5 & Teacher 5 & 70.4 & C ( Fair) \\
6 & Teacher 6 & 69.9 & D (Less) \\
& Average & 69.3 & D (Less) \\
\hline
\end{tabular}

Table 1 of the pre-cycle observation results shows the average score of the teacher's ability to arrange knowledge assessment instruments in the form of multiple-choice, the average content and description is 69.3 with the predicate D (less). From the data, it encourages action research through collaborative academic supervision.

The supervision of SDN Kenteng 01 Bandungan in cycle 1 began with planning which included program preparation, a schedule of steps, preparation of instruments, supervision, and outreach to the teachers. In the early stages of pre-observation, the school principal delivered the program, the goal to the teacher based on the focus of the problem, collaborative academic supervision in cycle 1 was carried out in 2 meetings, namely January 7, 2020, and January 8, 2020, through planning, implementing, observing, reflecting steps. Meeting 1 cycle 1 begins with an initial conversation conveying the goals and objectives of supervision. In implementing the actions of the school principal with the teacher discussing instruments, delivering material on the steps for writing questions, and guiding the teacher in preparing the questions. Through this collaborative approach, teachers are given the opportunity to discuss. Supervisors provide worksheets for preparing questions and guide teachers and observe the process and results of teacher work. At the second meeting, cycle 1 was no different from the implementation of meeting 1 , namely through the steps a) initial conversation; b) observation of the preparation of questions with guidance; c) review discussion questions; d) analysis of results and d) meeting back to reflect; f) follow-up results of analysis and reflection (Sahertian, 2010). Analysis of the results and reflection is carried out to determine the success rate of the specified actions and aspects that need to be improved in the next cycle. The results of the data analysis can be seen in Table 2 . 
Table 2. Results of the Teacher's Ability Score Analysis of Developing Knowledge Assessment Instruments in Cycle 1

\begin{tabular}{llcccccc}
\hline No & Subject & $\begin{array}{c}\text { Multiple } \\
\text { Choice }\end{array}$ & $\begin{array}{c}\text { short } \\
\text { entries }\end{array}$ & Description & Average & Predicate & completeness \\
\hline 1 & Teacher 1 & 80 & 75 & 81 & 78.7 & $\mathrm{C}$ & \\
2 & Teacher 2 & 75 & 76 & 77 & 76 & $\mathrm{C}$ & \\
3 & Teacher 3 & 81 & 77 & 78 & 78.7 & $\mathrm{C}$ & $16.7 \%$ \\
4 & Teacher 4 & 78 & 79 & 75 & 77.3 & $\mathrm{C}$ & \\
5 & Teacher 5 & 83 & 81 & 86 & 83.3 & B & \\
6 & Teacher 6 & 79 & 82 & 77 & 79.3 & $\mathrm{C}$ & \\
& Average & 79.3 & 78.3 & 79 & 78.9 & $\mathrm{C}$ & \\
\hline
\end{tabular}

The results of observations and data analysis on the ability of teachers in cycle 1 show that the average ability of 6 teachers in compiling knowledge assessment instruments in the multiple-choice form is an average of 79.3 that is a fair predicate (C), in short entries question form is an average of 78.3 that is the fair predicate. (C), the average of questions in the description is 79 that is a fair predicate $(\mathrm{C})$. The average of the 3 question forms was 78.9 that is a fair predicate $(\mathrm{C})$. This shows that the expected abilities have not reached the indicators of success criteria. The average score for the 3 question forms was 78.9 with the Fair predicate (C). From these data, it is known that 1 teacher received a Good predicate (B) while 5 received a score of Fair predicate (C). Based on these data, it shows that teachers who have achieved the completeness of the success indicators are $16.7 \%$ while the remaining of $83.3 \%$ have not yet achieved the specified completeness of success. The data in cycle 1 has shown an average increase from pre-cycle to cycle 1 was $13.9 \%$, but the indicators of research success have not been achieved. In terms of weakness-translation in cycle 1, it is necessary to plan a follow-up in cycle 2 to make improvements until it reaches the set standard of success. From the results of the analysis cycle 1 reflected through the activities: a) brainstorming solutions to problems and obstacles faced; b) determination of problem solutions; c) motivation and strengthening to teachers. d) agree on improvements at a later stage.

Cycle 2 begins with planning. The activity is planned for 2 meetings, namely on February 3 and February 4, 2020. Planning cycle 2 includes: supervision program, schedule, instruments, scenarios, and supporting facilities. The implementation of the actions in cycle 2 includes: a) initial activities with an agreement conversation with the teacher; b) convey the objectives of the supervision; c) guidance in the preparation of questions; d) observation; f) analysis of results; g) reverse meeting discussion; In cycle 2 observation, the supervisor observes the process and the results of which questions include multiple choice questions, short entries and descriptions. The aspects studied include question identity, instructions, answer keys, assessment guidelines, material, question construction, and language aspects. The results of the question analysis were then analyzed to determine the level of success (Table 2).

Table 2. Results of Teacher Ability Score Analysis to Arrange Knowledge Assessment Instruments in Cycle 2

\begin{tabular}{llcccccc}
\hline No & Subject & $\begin{array}{c}\text { Multiple } \\
\text { Choice }\end{array}$ & $\begin{array}{c}\text { short } \\
\text { entries }\end{array}$ & Description & Average & Predicate. Completeness \\
\hline 1 & Teacher 1 & 92 & 92 & 92 & 92 & $\mathrm{~A}$ & \\
2 & Teacher 2 & 91 & 90 & 90 & 90.3 & B & \\
3 & Teacher 3 & 89 & 88 & 89 & 88.7 & B & \multirow{2}{*}{$100 \%$} \\
4 & Teacher 4 & 90 & 88 & 89.7 & 89.2 & B & \\
5 & Teacher 5 & 94 & 93 & 93 & 93.3 & A & \\
6 & Teacher 6 & 91 & 88 & 87.5 & 88.5 & B & \\
& Average & 91.2 & 89.8 & 90.2 & 90.5 & B & \\
\hline
\end{tabular}


Based on the analysis of the observation results in cycle 2, it is known that the ability of 6 teachers to arrange knowledge assessment instruments on multiple-choice questions was average 91.2 Very good predicates (A), on short entries question was average of 89.8 Good predicates (B), on description question was average 90.2 Good predicate (B). From the three questions, the average score was 90.4 Good predicate (B). From these data, it is known that 2 teachers $(66.7 \%)$ received a Very good predicate (A) and 4 teachers $(33.3 \%)$ received a Good predicate (B). Thus it can be seen that $100 \%$ of the teachers have accomplished the success indicators set out in this study. Based on these data, it is known that there is an improvement from cycle 1 to cycle 2 that is $14.6 \%$, with $100 \%$ completeness.

Reflection cycle 2 includes a) brainstorming with the teacher; b) strength and motivation to teachers. The results of the analysis on reflection cycle 2 concluded that the implementation of supervision carried out by the school principal had gone through the stages of planning, pre-observation, implementing supervision, evaluation, analysis, and follow-up in accordance with the program.

Based on pre-cycle observations, it is known that the ability of teachers in compiling instruments for assessing aspects of knowledge at SDN Kenteng 01, Bandungan District is still in the poor category because teachers are still experiencing difficulties and have not implemented academic supervision that focuses on the preparation of knowledge assessment instruments. This encourages to conduct of supervisory action by the school principal to improve the ability of teachers to compile knowledge assessment instruments with collaborative academic supervision. Academic supervision with a collaborative approach at SDN Kenteng 01, Bandungan District is carried out through planning, implementation, evaluation and follow-up steps in accordance with the plan. The plan and objectives of supervision are conveyed to teachers through meetings to build teachers' understanding in order to understand the objectives of the supervision being carried out. It is important to plan this supervision to provide clear direction and ensure its implementation. Collaborative supervision planning is the activity of preparing a supervision plan with the team and teachers. Planning includes programs, objectives, implementation time, steps, instruments, and team determination (Bahrodin, 2018: 45). This planning stage is in line with previous research (Leniwati \& Arafat (2017). The success of academic supervision is carried out through three steps, namely planning, implementation and evaluation. In planning, the principal submits the plan to the teacher and the teacher gives a positive response to the implementation of supervision..

The implementation of activities includes initial meetings, implementation by guiding teachers in preparing questions, conducting evaluations, analyzing the results of teacher work. Actions by the school principal to improve the ability of teachers to compile assessment instruments are carried out based on planned steps. The observations carried out in cycle 1 and cycle 2 included observation of the implementation and product of the questions by referring to aspects in the instrument.

Table 3. Comparison of Average Score of Teacher Ability to Arrange Assessment Instruments

\begin{tabular}{lcccc}
\hline Cycle & Average & Predicate & $\begin{array}{c}\text { Completeness } \\
\text { frequency }\end{array}$ & $\begin{array}{c}\text { Percentage of } \\
\text { Completeness }\end{array}$ \\
\hline Pre-cycle & 69.3 & $\mathrm{D}$ & - & - \\
cycle 1 & 78.9 & $\mathrm{C}$ & 1 & $17 \%$ \\
cycle 2 & 90.4 & $\mathrm{~B}$ & 6 & $100 \%$ \\
\hline
\end{tabular}

Table 3 shows the average of pre-cycle is 69.3 , cycle 1 is 78.9 (C) with success completeness of $16 \%$ and in cycle 2 is 90.5 that is a Good predicate (B) with $100 \%$ success completeness. These results show that from the pre-cycle after supervision in cycle 1 there was an improvement of $13.9 \%$. From cycle 1 to cycle 2 there is an improvement of $14.7 \%$. From pre-cycle to cycle 2 there is an improvement of $30.4 \%$. It is also known that the average score and completeness at the end of cycle 2 have reached the completeness of the success indicators specified in the research hypothesis. Thus it can be concluded that the collaborative academic supervision carried out by SDN Kenteng 01 is proven that it can improve the ability of teachers to compile knowledge instruments. 
Improving the ability of teachers in developing assessment instruments cannot be separated from the role of the school principal through academic supervision with steps in the theory of supervision. The results of previous studies indicate that academic supervision can improve teacher competence. Dwikurnaningsih \& Hartana's research (2018: 101-109) The results of the study show that academic supervision carried out by school principals can improve teacher quality. Similar research was done by Dwikurnianingsih \& Hartana (2018) with current research is school action research through academic supervision of a collaborative approach to improving pedagogical competence. This research is also in line with Giyarti's (2015). The results showed that academic supervision can improve the ability of classroom teachers to develop a syllabus, develop learning plans to implement learning. Other supporting research is the result from Widodo \& Ismanto \& Sadjito (2014). The results showed that the implementation of classroom visit supervision at SMP Negeri 1 Bandungan held two semesters of class supervision visits, it had an impact on teacher performance in planning which could be seen in better planning and complete administration, disciplined teachers for and implementing interactive learning coherent with various interesting methods and media.

The observational data of this study and supported by the results of these studies indicate that improving the ability and performance of teachers cannot be separated from the role of the school principal as a supervisor. The school principal has a very important role in improving teacher performance in improving the quality of learning. The concept of the school principal as a supervisor is characterized by progress in the school and it appears after the school principal has assisted with teacher difficulties (Sagala, 2012:134). Triwiyanto, Suyanto, and Prasojo (2019) stated that the inhibiting factors for management in schools are study time is not maximal and students' lack of focus in learning. By doing continuous improvement, the quality of education will increase.

Supervision has an important role in improving the quality of learning. Previous research results indicate that academic supervision affects improving teacher competence. Astuti's research (2016). The results show that academic supervision is proven to improve the ability of teachers in compiling administrative assessments with $26.2 \%$ improvement. Hasan's research (2017) showed that applied academic supervision can improve the competence of teachers at SMA Negeri 1 Syamtalira Aron, Aceh in compiling an administrative assessment of $15.4 \%$. In line with that Mujiharti's (2016) research results showed that the academic supervision of class visits can improve teacher performance in compiling Learning Implementation Plans, implementing learning, and evaluating learning outcomes. Likewise, Suyadi's research (2015) conducted school action research through supervision of classroom visits at SD Negeri Mijen Demak. The results of his research reflected that supervision by using classroom visit techniques can improve the ability of teachers to design learning and assessment tools. Thus, the results of these studies mutually support one another, and it can be concluded that academic supervision can improve teacher quality.

Academic supervision is an effort to improve the quality of learning. The definition of supervision, in general, is an effort to improve learning. According to Purwanto (2012: 76), supervision is an activity to foster and provide assistance for teachers to be able to carry out work effectively. Meanwhile, according to Pidarta (2009: 2) education supervision is a coaching activity for teachers to improve learning. According to Daresh (Mulyadi \& Fahriana, 2018: 1), academic supervision is an activity by helping teachers to develop their abilities to achieve learning goals. The definition of supervision according to the Charter Good's Dictionary of Education (Mulyasa, 2003: 155), academic supervision is all efforts to foster teachers and education personnel, by providing stimulation, improving goals, using methods, subject matter, methods, and assessment. Learning supervision is an activity to help teachers improve their ability to manage learning (Iskandar, 2009:51). Nawawi (in Mushlis \& Suryadi, 2018), supervision is a service carried out by the principal to help teachers to improve professionalism so that they can improve the effectiveness of learning. Daryanto (2015: 196) states that supervision is a planned, patterned activity to change teacher behavior so that it can improve the quality of learning.

From these various thoughts, it can be concluded that academic supervision is an activity carried out in a planned manner, to provide services and assistance to teachers by providing motivation, stimulation, directing, so that teachers develop professionalism to improve the effectiveness and quality of learning. 
Academic supervision is an effort to motivate and improve teacher performance to be more innovative. As stated by Suharsaputra (2018: 26), academic supervision needs to be developed through new practices to make better educational innovation, quality, and productive change.

Academic supervision will achieve goals with plans. According to Sergiovanni (in Mukhtar \& Iskandar, 2009: 53), the objectives of learning supervision are: a) increasing the effectiveness and efficiency of learning; b) monitoring the quality of the learning process in schools; c) professional development, teachers in understanding learning develop their teaching skills; d) motivate teachers to be responsible for carrying out their teaching duties. According to Sagala (2012: 104) supervision aims to help teachers develop the learning process, improve the quality of learning by using sources and various media and develop teacher professionalism. Meanwhile, according to Yushak Burhanuddin (in Mulyadi \& Fahriana (2018: 3-4) academic supervision aims to help teachers solve problems, fix deficiencies, improve the effectiveness and efficiency of learning, and control learning implementation. According to Sahertian (2010: 19), supervision aims to provide services and assistance to teachers to improve the quality of learning, develop teacher potential to improve the quality of student learning. Meanwhile, Mulyadi (2018: 3) academic supervision aims to improve the teaching and learning situation, both teacher and student situations.

In carrying out academic supervision, it needs to pay attention to the principles of academic supervision. According to Sahertian (2010: 20-21), academic supervision will work well by paying attention to the principles of a) scientific, where data is made objectively, using data recording devices, and is carried out systematically; b) Democratic, that is supervision is carried out based on a friendly relationship full of intimacy, respecting teachers, not based on superiors and subordinates; $\mathrm{c}$ ) cooperation to provide mutual support between one another; d) develop the potential and creativity of the teacher. In addition to these principles, supervision needs to be carried out practically, systematically, objectively, realistically, actively, anticipatively, integrated, comprehensively, and continuously (Mushlih \& Suryadi, 2018:55). Practical means that supervision is easy to carry out according to systematic implementation through program planning and goal setting. In order to obtain correct data, it needs to pay attention to objective principles, it means that it is in accordance with the aspects of the instrument. With realistic principles, this means that supervision is carried out following the real facts. Supervision will be successful if it is based on active principles. This means that both supervisors and teachers are equally active. The principle of anticipation in supervision is the ability to face problems that will occur during supervision activities. Integrated means that supervision is part of the educational program. Comprehensive means that academic supervision fulfills learning objectives.

Supervision is carried out through various approaches. According to Sahertian (2010: 46-47), there are three approaches to academic supervision, namely the direct approach, the indirect approach, and the collaborative approach. In a direct approach, the supervisor provides direct directions to the teacher regarding the shortcomings and problems faced by the teacher. For instance, with examples and descriptions so that the teacher understands what the supervisor explains. It is different from the direct approach. In the indirect approach, the supervisor's supervision gives the teacher the opportunity to reveal the problem and the supervisor listens first. Then the supervisor provides reinforcement, explains, actively helps solutions to problems raised by the teacher, while the collaborative approach is an approach that combines direct and indirect approaches. In this approach, the supervisor's activity is negotiating, active two-way communication with the teacher to discuss problems together and the supervisor directs to reach an agreement so that the problem is resolved properly. According to Pidarta (2009: 117), collaborative-based academic supervision is supervision by collaborating between teachers and supervisors in solving learning problems in the classroom. To support this opinion, Dharma 2009 (in Bahrodin, 2018: 10) mentioned that academic supervision with a collaborative strategy is one of the supervisors' efforts to carry out actions to assist teachers to achieve the stated supervision goals. According to Jumara, 2008 (in Bahrodin, 2018: 13) the principle of academic supervision that is built in collaboration is maximum cooperation in an atmosphere that is conducive, fun, mutual respect, and open. 
From these opinions, it can be concluded that a collaborative approach is a supervision approach that problem solving is carried out jointly with two-way communication between the supervisor and the teacher to reach an agreement. Thus a collaborative academic supervision approach will create a pleasant atmosphere.

The implementation of academic supervision includes planning, implementation, evaluation, and follow-up and reporting stages. According to Bahrodin (2018: 45-46), the planning stage includes: a) determining objectives, timing, approaches, methods/techniques; b) planning a realistic program; c) preparing a visit schedule; d) planning the steps for the pre-observation, observation, data analysis, follow-up, reporting, and monitoring stages; e) socializing to all target teachers of supervision; f) preparing supervision instruments.

The implementation stage begins with an initial meeting to build good relations, agreement, coordination, familiarity, openness, and preparation of instruments. At the implementation stage of schedule information, delivery of observation material, observation of planning documents, teaching and learning process, and assessment. The final stage of supervision. The final stage is a return meeting to discuss weaknesses and solutions. The evaluation stage includes evaluation and measurement of teacher competence based on the results of observations on the implementation of learning and assessment. In the follow-up stage, supervision is feedback for each teacher based on the results of monitoring of planning, implementation, and assessment. At the reporting stage, the supervisor prepares a report based on the results of supervision, evaluation, follow-up.

According to Sahertian (2010:51), Collaborative academic supervision measures include initial conversation, observation, data analysis, final conversation, and final analysis. The initial stage of the conversation is carried out by the supervisor with the teacher discussing the focus of the problem to be supervised, goals, and mutual agreement. At the observation stage, the supervisor observes the class or the teacher invites the supervisor to use the instrument that has been prepared. In the analysis stage, the observation data were analyzed and interpreted. The final conversation stage was carried out with discussions with the teacher to discuss the results of the analysis through the results of observations. Thus it can be concluded, collaborative academic supervision was carried out through the initial stages of planning, implementing by observation, recording the results of observations, evaluating by analyzing the results of observations involving the teacher, and following up with monitoring.

Teachers should understand assessment. Assessment according to the Regulation of the Minister of Education and Culture of the Republic of Indonesia Number 23 of 2016, assessment is a process of collecting and processing information to measure the achievement of student learning outcomes. Understanding assessment according to Majid (2017: 35), assessment is an integrated part of the learning process to obtain information used to determine the level of learning success. Meanwhile, according to Arikunto (2018: 3), assessment means activities that are preceded by measurements to obtain information and decisions that have good or bad results. According to Kunandar, (2015: 61) assessment of learning outcomes is carried out to determine the success and mastery of students on the learning competencies that are being carried out. According to Gronlund (in Arifin, 2015: 4) defines assessment is a process of collecting information that is carried out systematically, analyzed, and interpreted to determine the achievement of learning objectives.

Assessment of learning outcomes has a purpose. As for the purpose of the assessment, the objectives of the assessment are: to find out the progress and ability of students, to check the extent to which the competencies that have been mastered and which have not been mastered by students and used as input for teachers to make improvements and enrichment for students (Kunandar, 2015:70). The assessment aims to determine: a) the level of mastery of the students b) skills, motivation, talents, interests, and attitudes of the students; c) the progress of the students; d) strengths and weaknesses of the students; e) determination of class promotion and graduation (Arifin, 2009: 15). According to Sujana (in Majid 2017: 28), the assessment aims to describe students' learning ability to measure learning success, determine follow-up and make reports to related parties. Meanwhile, according to Arikunto (2018: 18), the assessment functions include a) to select 
students in choosing to continue school, class promotion, graduation; b) to diagnose students to find out the weaknesses; c) to determine precisely a student according to ability; d) to measure the success of an implemented program. the purpose of the assessment is to know the level of mastery of the students on the subject, to know the progress of the students, to determine class promotion, graduation and to know the success of learning, and to place students appropriately according to their abilities.

Assessment of learning outcomes implements principles. In order for the assessment to be in accordance with the standards, it needs to pay attention to the principles of validity, objectivity, fairness, integration, open comprehensive systematic, based on criteria and accountability (Kemdikbud, 2016: 8). The assessment must pay attention to the valid principle, so the assessment must be based on the measured data. In order for the assessment to be objective, it must use clear procedures and criteria. Assessment must be carried out fairly in order to benefit all students. assessment is an integral part of the lesson, so it must be carried out in an integrated manner, with an open principle, the results of the assessment can be known by all concerned. It covers all competency aspects, is planned with standard steps, refers to established criteria and the process and results can be accounted for. Based on the description mentioned above, to realize a good assessment, it needs to pay attention to the principles of assessment, so that the assessment carried out is successful in accordance with the expected objectives.

The scope of the assessment includes 3 aspects, namely the assessment of attitudes, knowledge, and skills (Kemdikbud, 2016: 8). Attitude assessment is an assessment of the daily behavior of students in the learning process and outside of learning. To measure the competence of students on the mastery of the basic competencies being taught. The assessment is carried out in the form of a written, oral, and assignment test. While the skills assessment is an assessment to measure the skills aspects of students which include performance, projects, and portfolios. According to Kunandar (2015: 165) knowledge assessment is to measure the level of mastery or understanding of the students towards certain knowledge. Meanwhile, skill knowledge is an assessment to measure the skill aspects of the students which include work, projects and portfolios. According to Anderson (Majid 2017: 182), knowledge assessment is an assessment of intellectual potential which consists of the stages of knowing, understanding, applying, analyzing, synthesizing, and evaluating. It can be concluded that the knowledge assessment is an assessment to measure the students's mastery competence in the form of oral, written and assignment tests which include memory, understanding, application, analysis and synthesis carried out.

The assessment stages include planning, implementation, analysis, follow-up and reports. According to Permendikbud RI Number 23 of 2016, the assessment of knowledge aspects is carried out through the following stages: a) planning; b) arrangement of instruments; c) implementation of the assessment; d) use of the results of the assessment; and e) reporting. Assessment planning includes: a) Determining basic competence; b) develop question indicators; c) determine the implementation time; d) determine the type of test form; e) determine the items f) determine the coverage of the test material; g) determine the proportion of the items $\mathrm{h}$ ) determine the distribution of the difficulty level of the questions; i) construct a grid of questions (Sani 2019:179)

From this description, it can be concluded that in carrying out the assessment it is necessary to take planning steps so that the assessment is more focused and goals can be achieved. The knowledge assessment instrument arranged in the form of test questions must meet the criteria for good test questions. A good test must be valid, reliable, objective, practical, and economical (Arikunto, 2018: 94). A valid test can measure exactly what will be measured. For a reliable test if the results show permanence. In order for the test to be successful, the test is carried out prioritizing high objectivity. A good test is a practical one that is easy to apply, corrected by the teacher, the economist does not cost a lot of money and effort.

Several previous studies have shown that supervision has an influence on improving teacher competence. Rukayah's research (2018) concluded that group supervision with a collaborative approach 
can improve the competence of lower-class teachers at Ungaran 05 Elementary School in preparing thematic learning planning. Rukayah's (2018) research equation with this research is action research through academic supervision with a collaborative approach that aims to improve the competence of the pedagogical aspects. Whereas the difference, in Rukayah's research, the competence of teachers in the planning aspect of preparing lesson plans, while in this study, which was improved in the aspect of the ability of the teacher to compile the assessment instrument for the knowledge aspect (cognitive).

Leniwati \& Arafat's (2017) research shows that the implementation of academic supervision is carried out through planning, implementation, and evaluation. The conclusion of Liniwati \& Arafat's research is that with supervision teachers give positive responses to the implementation of academic supervision to change teacher a better performance. The research equation of Leniwati \& Arafat (2017) with this research is knowing the implementation of supervision. The difference is, in Leniwati \& Arafat's research (2017 is survey research, while this research is a school action research to determine the improvement in the ability of teachers to develop assessment instruments with a collaborative approach).

Saleh, Mohamad \& Ali's (2016) research shows that education supervision is positively correlated with teacher performance in teaching English. In addition, the training program plays an important role as a mediating variable having the indirect positive impact of education supervision on teacher teaching performance. Ayeni's research (2012) shows that most school principals pay attention to monitoring teacher attendance, learning preparation, and the adequacy of work diaries. This study concludes that the challenges faced by school principals in school management, resources, curriculum, and student learning require synergistic collaboration between school objectives and stakeholders.

The results of Kuntari's research (2015) showed that the teacher performance of 6 people is in a Good category and 1 person is in the Fair category. The conclusion of this study is that the application of academic supervision at SD Walitelon Utara Temanggung can improve teacher performance in learning. This research is a school action research. The similarity of Dwi Kuntari's (2015) research with this study is using school action research with academic supervision to improve aspects of pedagogical competence, but there are differences with this research. Kustiyah's (2017) research results showed that the school principal's academic supervision with an individual approach can improve the performance of elementary school teachers in planning learning, implementing learning, and evaluation. The similarity of Kustiyah's 2017 research with this study is school action research through academic supervision to improve pedagogical competence.

\section{CONCLUSION AND SUGGESTION}

Based on the results of observations and pre-cycle data analysis, cycle 1 and cycle 2, collaborative academic supervision shows that after the existence of academic supervision with a collaborative approach, there is an improvement in the ability of teachers to develop instruments for assessing aspects of knowledge at SD Negeri Kenteng 01, Bandungan District. It was shown that there was an improvement in the score increase from pre-cycle to cycle 2 by $30.4 \%$. The success rate of $100 \%$ in cycle 2 shows the achievement of indicators of success in this study. From the data analysis, it can be concluded that academic supervision with a collaborative approach at SD Negeri Kenteng 01 is proven to improve the ability of teachers to develop assessment instruments on the knowledge aspect by $30.4 \%$. Collaborative academic supervision by planning steps, pre-observation, implementing observations, data analysis, final reflection meetings, and follow-up collaborative academic supervision can improve the ability of teachers at SD Negeri Kenteng 01, Bandungan District to compile a knowledge aspect assessment instrument. 


\section{REFERENCES}

Arifin, Z. 2015. Evaluasi Pembelajaran. Bandung: Remaja Rosda Karya

Arikunto, S. 2018. Dasar-Dasar Evaluasi Pendidikan. Jakarta: Bumi Aksara.

Astuti, S, 2016 Penerapan Supervisi Akademik Untuk Meningkatkan Kompetensi Guru Dalam Menyusun Administrasi Penilaian di SD Laboratorium UKSW. Jurnal Scholaria, 6(1), 117-126.

Ayeni, A.J. 2012. Assessment of Principals'Supervisory Roles for Quality AssuranceIn Secondary Schools in Ondo State, Nigeria. World Journal of Education, 2(1), 45-56.

Bahrodin. 2018. Supervisi Akademik Kolaboratif. Jakarta: Media Guru

Daryanto. 2013. Supervisi Pembelajaran, Yogyakarta: Gava Media

Dwikurnaningsih, Y., Hartana, N. 2018. Supervisi Akademik Melalui Pendekatan Kolaboratif Oleh Kepala Sekolah Dalam Meningkatkan Kualitas Pembelajaran di SD. Jurnal Satya Widya. 34(2), 67-77.

Giyarti, S. 2015. Peningkatan Kompetensi Pedagogik Guru SD Melalui Supervisi Akademik. Scholaria Jurnal Pendidikan dan Kebudayaan, 5(3), 34-45.

Hasan, M. 2017. Penerapan Supervisi Akademik untuk Meningkatkan Kompetensi Guru Dalam Menyusun Administrasi Penilaian, di SMA Negeri 1 Syamtalira Aron Tahun 2017. Jurnal Media Inovasi Edukasi, 04(15), 78-86.

Kusumaningrum, D.E., Sumarsono, R.B., and Gunawan, I. 2019. Professional Ethics and Teacher Teaching Performance: Measurement of Teacher Empowerment with a Soft System Methodology Approach. International Journal of Innovation, Creativity and Change. Volume 5, Issue 4, Special Edition: ICET Malang City, 2019. www.ijicc.net

Kunandar. 2015. Penilaian Autentik Penilaian Hasil belajar Peserta Dididk Berdasarkan Kurikulum 2013 Suatu Pendekatan Praktis. Jakarta: PT Raja Grafindo Persada

Kustiyah. 2017. Meningkatkan Kinerja Guru Melalui Supervisi Akademik Kepala Sekolah Dengan Pendekatan Individual Di SD Candi 01 Kecamatan Candisari Kota Semarang. Jurnal Malih Peddas. 7(1), 89-98.

Leniwati Yasir \& Arafat, Y. 2017. Implementasi Supervisi Akademik Kepala Sekolah Untuk Meningkatkan Kinerja Guru. Jurnal Manajemen, Kepemimpinan, dan Supervisi Pendidikan, 2(1), 23-35.

Majid, A. 2017. Penilaian Autentik .Bandung: PT Remaja Rosda Karya.

Menteri Pendidikan dan Kebudayaan. 2018 . Pemenuhan Beban Kerja Guru, Kepala Sekolah, Dan Pengawas Sekolah

Menteri Pendidikan dan Kebudayaan. 2016. Panduan Penilaian Untuk Sekolah Dasar

Menteri Pendidikan dan Kebudayaan. 2016. Peraturan Menteri Pendidikan dan Kebudayaan Nomor 23 Tahun 2016 Tentang Standar Penilaian untuk Satuan Pendidikan Dasar dan Menengah.

Menteri Pendidikan Nasional. 2005. Peraturan Menteri Pendidikan Nasional Republik Indonesia Nomor 19 Tahun 2005 tentang Standar Nasional Pendidikan.

Menteri Pendidikan Nasional. 2007. Peraturan Menteri Pendidikan Nasional No. 16 Tahun 2007 tentang Standar Kompetensi Guru.

Menteri Pendidikan Nasional. 2007. Permendiknas Nomor 13 tahun 2007 tentang Standar Kompetensi Kepala Sekolah

Mujiharti.2016.,Peningkatan Kinerja Mengajar Guru Melalui Supervisi Akademik Kunjungan Kelas oleh Kepala Sekolah di SDN 2 Sarirejo Kecamatan Kaliwungu Kabupaten Kendal. Salatiga: UKSW

Mukhtar \& Iskandar. 2009. Orientasi baru Supervisi Pendidikan, Jakarta: Gaung Persada

Mulyadi \& Fahriana A. 2018 . Supervisi Akademik, Konsep, Teori, Model Perencanaan, dan Implikasinya. Malang: Madani

Mulyasa, E. 2003. Manajemen Berbasis Sekolah, Bandung: PT Remaja Rosda Karya

Mulyasa, E. 2009. Penelitian Tindakan Sekolah, Bandung: PT Remaja Rosda Karya.

Mushlih, A, Suryadi,R. 2018. Supervisi Pendisikan Teori dan Praktik. Bandung : PT Remaja Rosdakarya.

Pidarta, M 2009. Supervisi Pendidikan Kontekstual. Jakarta : PT Rineka Cipta

Presiden Republik Indonesia. 2003. Undang-Undang Republik Indonesia Nomor 20 Tahun 2003, tentang Sistem Pendidikan Nasional.

Presiden Republik Indonesia. 2005. Undang-Undang Nomor 14 Tahun 2005 tentang Guru Dan Dosen.

Purwanto, Ngalim. 2012 Administrasi dan Supervisi Pendidikan. Bandung: Remaja Rosdakarya. 
Rukayah, 2018. Peningkatan Kompetensi Guru Dalam Perencanaan Pembelajaran Tematik Melalui Supervisi Kelompok Pendekatan Kolaboratif. Jurnal Kelola, 5(1), 87-99.

Sagala, S. 2012. Supervisi Pembelajaran Dalam Profesi Pendidikan. Bandung: Alfabeta.

Sahertian, Piet A. 2010 Konsep Dasar dan Teknik Supervisi Pendidikan dalam Rangka Pengembangan Sumber Daya Manusia,. Jakarta: Rineka Cipta.

Sancara, A., Atalb, D., and Deryakulub, D. 2021. A new framework for teachers' professional development. Teaching and Teacher Education. Volume 101, May 2021, 103305. https://www.elsevier.com/journals/teaching-andteacher-education-leadership-and-professional-development/2667-3207/open-access-information.

Sani, R.A. 2019. Penilaian Autentik. Jakarta: Bumi Aksara.

Shakuna, K. S., Mohamad, N., Ali, A.B., 2016 The Effect of School Administration and Educational Supervision on Teachers teaching performance: Training Programs as a Mediator Variable. Asian Social Science, 12(10).116125.

Sugiono, 2014. Memahami Penelitian Kualitatif. Bandung: Alfabeta

Suharsaputra, U. 2018. Supervisi Pendidikan Pendekatan Sistem Berbasis Kinerja. Bandung: Refika

Sukardi. 2008. Metodologi Penelitian Pendidikan. Jakarta: PT Bumi Aksara.

Triwiyanto, T., Suyanto. and Prasojo, L. D. 2019. The Thoughts of Ki Hadjar Dewantara and Their Implications for School Management in the Industrial Era 4.0, International Journal of Innovation, Creativity and Change, 54, p. 12-24.

Ulfatin, N., Mustiningsih, Sumarsono, R.B. and Yunus, J.N. 2020. School-based management in marginal areas: Satisfying the political context and student needs. Management in Education 1-11. journals.sagepub.com/ home/mie DOI: 10.1177/0892020620959739

Widiasworo, E. 2018. Mahir Penelitian Pendidikan Moderen. Yogyakarta: Araska

Widodo, T., Ismanton, B., Sadjito. A. 2014. Supervision of Classroom Visits in Improving Performancescience Teachers Ofstate Junior High School 1 Bandungan. Jurnal International Conference on Fundamentals and Implementation of Education ICFIE UNY. 